保健物理， 15，135 146（1980)

資料

\title{
自然放射線に対する建築物遮蔽効果とその 国民線量評価への影響*1
}

中村尚司 $* 2$, 伊藤和男 $* 3$, 義村利秋 $* 4$

\author{
(1979年11月13日受理)
}

(1980年 1 月11日再受理)

\begin{abstract}
Shielding Effect of Building to Natural Radiation and Its Influence
to Population Dose Evaluation*1
\end{abstract}

Takashi Nakamura, ${ }^{* 2}$ Kazuo IToh, ${ }^{* 3}$ and Toshiaki Yoshimura*4

This work investigated the shielding effect of the building which is indispensable for the accurate evaluation of the population dose of external exposure from natural radiation.

At first, the attenuation coefficients of various building materials were measured and found to agree with the calculated values within $10 \%$ errors. The shielding factors of these materials were calculated from the calculated attenuation coefficients and buildup factors.

The shielding factors of the wall, window, roof and floor were calculated separately by settling the model houses and combining the shielding factors of the building materials used, and then the shielding factor of the whole building was obtained by use of the opening fraction of the wall and the fractions of the wall, roof and floorareas to the total floor area.

The influence of the shielding effect of the building is well represented by the occupancy factor which is the ratio of the group doses including that shielding effect to those excluding it. The occupancy factor lies between 0.9 and 1.0 for four specified districts, Tokyo, Osaka, Ibaraki and Nagano.

KEY WORD : shielding effect, building, natural radiation, population dose, external exposure, occupancy factor, model house, attenuation coefficient, buildup factor.

*1 本資料は (財) 放射線影響協会が放射線医学総合研究所 より委託をらけた研究成果 (昭和 52 年 ${ }^{1}$ ), 53 年 2 )) の 一部をとりまとめたものである。

*2 東京大学原子核研究所放射線管理室; 東京都田無市緑町 3-2-1 ( 1 188)

Radiation Control Center, Institute for Nuclear Study, Univ. of Tokyo; Midori-cho 3-2-1, Tanashi, Tokyo.

*3 建築研究所第 2 研究部; 茨城県筑波郡大穂町立原 1 (下305)

Building Research Institute, Second Div.;"Tachihara 1, Oho-cho, Tsukuba, Ibaraki.

*4 政策科学研究所; 東京都千代田区永田町 2-4-11 (T100)

Institute for Policy Sciences; Nagata 2-4-11, Chiyoda, Tokyo.

\section{I 序論}

放射線利用の急激な発展と低線量被曝の影響に関する 研究の進展に伴い，人類とその環境への放射線の影響が 重要な問題になってきている。この影響評価のためには 国民全体にわたる被曝（国民線量）を推定することが必 要である。

国民線量推定のための基礎調査委員会の報告書「国民 線量推定のための基礎調査」1,2)の中で述べられているよ らに，国民線量の推定にあたっては線量に奇与する放射 線源の種類とその大きさを評価することが必要であり, そこでは自然放射線源による外部被曝のみを対象とし 
て，多くのパラメータを含む国民線量推定モデルを作成 している。本研究では，このモデルに含まれるパラィー タのうちの建築物の遮蔽効果に着目し, その遮蔽効果が 国民線量推定に及ぼす影響の程度について感度解析を主 眼と乙た評価を行なった。

これまで放射線の物質による遮蔽効果の研究は数多く なされているが，建築物の遮蔽効果に関する研究はほと んどないといっても過言ではない。本研究では，まず建 築物に用いられている各種建築材料の減衰係数之遮蔽率 を求め，ついで建物構造別にモデルハウスを設定して建 築物全体の遮蔽率を推定し，最後にこの建物遮蔽率の国 民線量への影響の程度を評価した。

\section{II 自然放射線の種類}

建物遮放効果の対象となる自然放射線源としては，上 記報告書 ${ }^{1,2)}$ に示したように線量寄与の大きい宇宙線と 大地・大気放射線の 2 つを考える。

宇宙線は直接電離成分（電子，光子， $\mu$ 中間子）と間 接電離成分（中性子）に大別できるが，地上 $1,000 \mathrm{~m}$ ぐらいまでは後者は無視できる。直接電離成分は $\mathrm{MeV}$ 領域から GeV 領域に向って単調減少するエネルギース ペクトルを持っているが3゙，数 $\mathrm{MeV}$ 付近から以下では 線量への寄与は比較的小さくなるといわれている。つま り宇宙線はその高エネルギー成分が線量に寄与する。ま た，宇宙線の入射方向の角度分布としては，ガンマ線成 分に対する測定值 ${ }^{4)}$ から下向きの成分が主であることが 分っている。

大地・大気放射線は ${ }^{40} \mathrm{~K}$ および U, Thの崩壊生成物 から放出される $\beta, \gamma$ 線が主成分である。ガンマ線のエ ネルギースペクトルは地域ごとに違う可能性が高いが， その差はあまり大きくないものとみて代表的な測定例を 第 1 図に示す5)。また，入射角度分布は日本 ${ }^{5)}$ 扎よびア メリカ6)での実测值から, 真下からくるものは少なく,

下方のほほ横方向からくる成分が大きいことがわかっ
ている。

\section{III 各種建築材料の減衰係数}

${ }^{60} \mathrm{Co}$ ガンマ線に対する各種建築材料の線減衰係数 $\mu$ を 測定した。测定配置を第 2 図に示す。線源は約 $34 \mathrm{mCi}$ の ${ }^{60} \mathrm{Co}$ で，鉛ータングステン製の容器に格納されてい る。放出されるガンマ線は，厚さ $100 \mathrm{~cm}$ の磁鉄鉣コン クリート壁を貫通する直径 $2.5 \mathrm{~cm}$ の孔によりコリメー トされ細いビームとしてとり出された。供試体を透過し たガンマ線は, 直径 $0.5 \mathrm{~cm}$ の穴のあいた $5 \mathrm{~cm}$ 厚の鉛 コリメータで遮蔽された $2^{\prime \prime} \phi \times 2^{\prime \prime} \mathrm{NaI}(\mathrm{Tl})$ シンチレー タで検出し, 多重波高分析器で波高分布を測定した。 ${ }^{60} \mathrm{Co}$ のガンマ線エネルギーを $1.25 \mathrm{MeV}$ とし，このエ ネルギーに対する線減衰係数 $\mu$ を

$$
I=I_{0} e^{-\mu x}
$$

の式から求めた。ここで $x$ は供試体の厚さ, $I, I_{0}$ は各

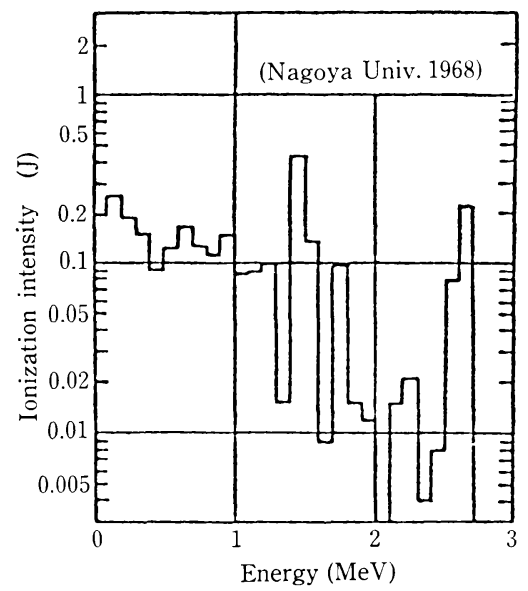

Terrestrial ionization intensity as a function of photon energy at ground level. (5)

第 1 図大地放射線のエネルギースペクトル 文献 5）から引用した

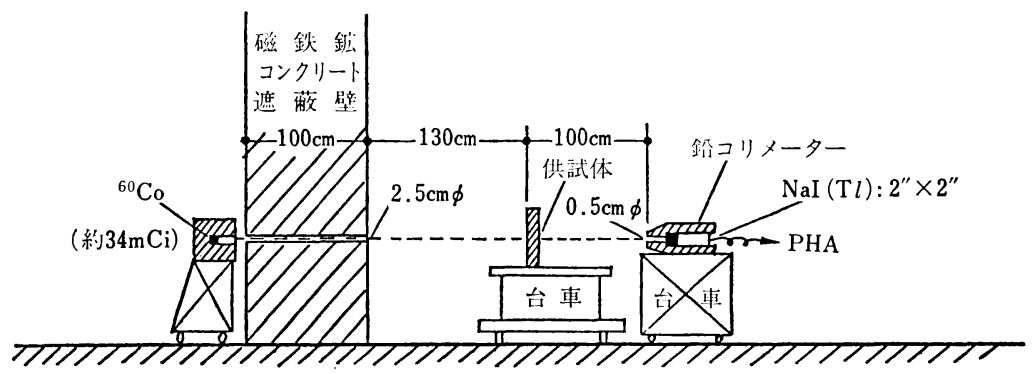

第 2 図建築材料の線減衰係数の測定配置図 
第 1 表 ${ }^{60} \mathrm{Co}(1.25 \mathrm{MeV})$ ガンマ線に対する各種建築材料の減衰係数

\begin{tabular}{|c|c|c|c|c|}
\hline \multirow{2}{*}{ 建築材料名 } & \multirow{2}{*}{$\begin{array}{c}\text { 線減衰係数実測值 } \\
\left(\mathrm{cm}^{-1}\right)\end{array}$} & \multirow{2}{*}{$\begin{array}{c}\text { 見かけ密度実测值 } \\
\left(\mathrm{g} / \mathrm{cm}^{3}\right)\end{array}$} & \multicolumn{2}{|c|}{ 質量減衰係数 $\left(\mathrm{cm}^{2} / \mathrm{g}\right)$} \\
\hline & & & 実測值 & 計算值 \\
\hline 化粧合板 & $0.0348 \pm 0.0059$ & 0.59 & $0.0590 \pm 0.010$ & \multirow{2}{*}{$0.0641^{*}$} \\
\hline 普通合板 & $0.0420 \pm 0.0081$ & 0.63 & $0.0667 \pm 0.013$ & \\
\hline 石コウボード & $0.0623 \pm 0.0054$ & 0.97 & $0.0642 \pm 0.0056$ & 0.0591 \\
\hline 石綿セメント板 & $0.0775 \pm 0.0077$ & 1.5 & $0.0517 \pm 0.0051$ & 0.0578 \\
\hline コンクリートブロック & $0.0663 \pm 0.0021$ & 1.21 & $0.0548 \pm 0.0017$ & 0.0578 \\
\hline 日本ガワラ & 0.0926 & 1.73 & 0.0535 & \multirow{2}{*}{0.0582} \\
\hline 洋ガワラ & 0.134 & 2.29 & 0.0584 & \\
\hline
\end{tabular}

*この值は水に対する值である。

各供試体を扎いた時と扔かない時の測定された波高分布 の光電ピーク部の面積である。

${ }^{60} \mathrm{Co}(1.25 \mathrm{MeV})$ に対する各種建築材料の線減衰係数 $\mu$ の測定值を見掛け密度 $\rho$ の実測值および質量減衰係数 $\mu_{\mathrm{m}}$ とともに第 1 表に示した。供試体表面の任意の 3 点 を選んで $\mu$ の測定を行ない, その 3 点の平均値をもって $\mu$ の値とした。測定誤差は 3 回の測定值の平均値からの ずれの平均値とした。したがってかわらについては測定 点が 1 点のため誤差を示していない。次章でのべる計算 法により求めた $\mu_{\mathrm{m}}$ の計算値も第 1 表に示したが, 測定 值とは約 $10 \%$ の䛊差内で一致しており, 測定値の誤差 を考慮すると計算值と测定值の一致は十分満足すべきも のであることが分った。

\section{IV 建築物遮蔽率の計算}

建物の遮蔽率を求める場合，まず代表的な何種類かの モデルハウスを考学るが，その要件となるのは

（i）各部 (屋根, 壁, 㦿) の材質, 層数, 各層の厚さ

（ii）開口率, 壁面積比, 屋根面積比, 床面積比 である。（i）については, 壁に対して文献 7）に基づい て, 構造別に, さらに各構造每に仕上げ材 (素材) 別に モデルハウスを設定し，それに基く結果が報告されてお $\eta^{11}$, 第 3 図に, その構造別壁エレメント構成表を引用 している。この図には用途別(住宅, 非住宅)に仕上げ材 別の存在割合も記されている。屋根扣よび床に対しても 同じデータが必要であるが, 非木造の場合は屋根および 床は壁に等しいと考えることにして，木造の場合の屋根， 床だけを考劣た。木造家屋の屋根, 㦿のエレメント構成 については文献 8$)$ をもとに作成された報告がなされて いる2。。ただし前に述べたよらに大地放射線がほぼ下方 横方向から建物化入射することを考えると, 壁面遮蔽率
が重要で、屋根や床の遮蔽効果はあまり重要でないとい 学る。（ii）については用途別にえられた結果1)が第 2 表 に引用されている。

（i），（ii）のデータをもとに建物遮蔽率を第 4 図に 示す順序に従って算出した。以下各項目を追って説明す る。

\section{1. 放射線源の種類, エネルギースペクトル, 角度分 布の決定}

大地・大気放射線のみを考えるのでその主成分はガン マ線であり, エネルギースペクトルは第 1 図比与えられ ている。角度分布は下方横方向からの入射が大きくなっ ているので, モデルハウスの遮蔽効果を考える場合, 屋 根, 壁, 床の全面に対し大地放射線が等方に一様に入射 する場台と, 壁の夕に入射する場合の両方が考兄られ, 実際にはこの両者の値の中間であって後者に近い值をと ると考えればよい。

\section{2. 平均エネルギーの決定}

第 1 図の大地放射線のエネルギースペクトルから各エ ネルギーに対する遮蔽率を求めるのは数多くの計算を必 要とするので, ここでは簡単な近似として, 線量寄与の 重み付き平均エネルギー $\bar{E}$ を求めて, これに対する遮 蔽率 $f_{\mathrm{k}}(\bar{E})$ を求めることにした。

$$
\bar{E}=\frac{\int_{0}^{E_{0}} \mu_{\mathrm{a}}(E) E \phi(E) \mathrm{d} E}{\int_{0}^{E_{0}} \mu_{\mathrm{a}}(E) \phi(E) \mathrm{d} E}
$$

である。ここで, $E_{0}=2.6 \mathrm{MeV}$

$\mu_{\mathrm{a}}(E):$ 空気のエネルギー吸収倸数

$\phi(E)$ : 大地放射線のエネルギースペクトル

であり, 計算の結果 $\bar{E}=0.914 \mathrm{MeV}$ を得た。

\section{3. 化合物, 混合物の質量および線減衰係数の計算}

建築材料として使用されている化合物，混合物の質量 


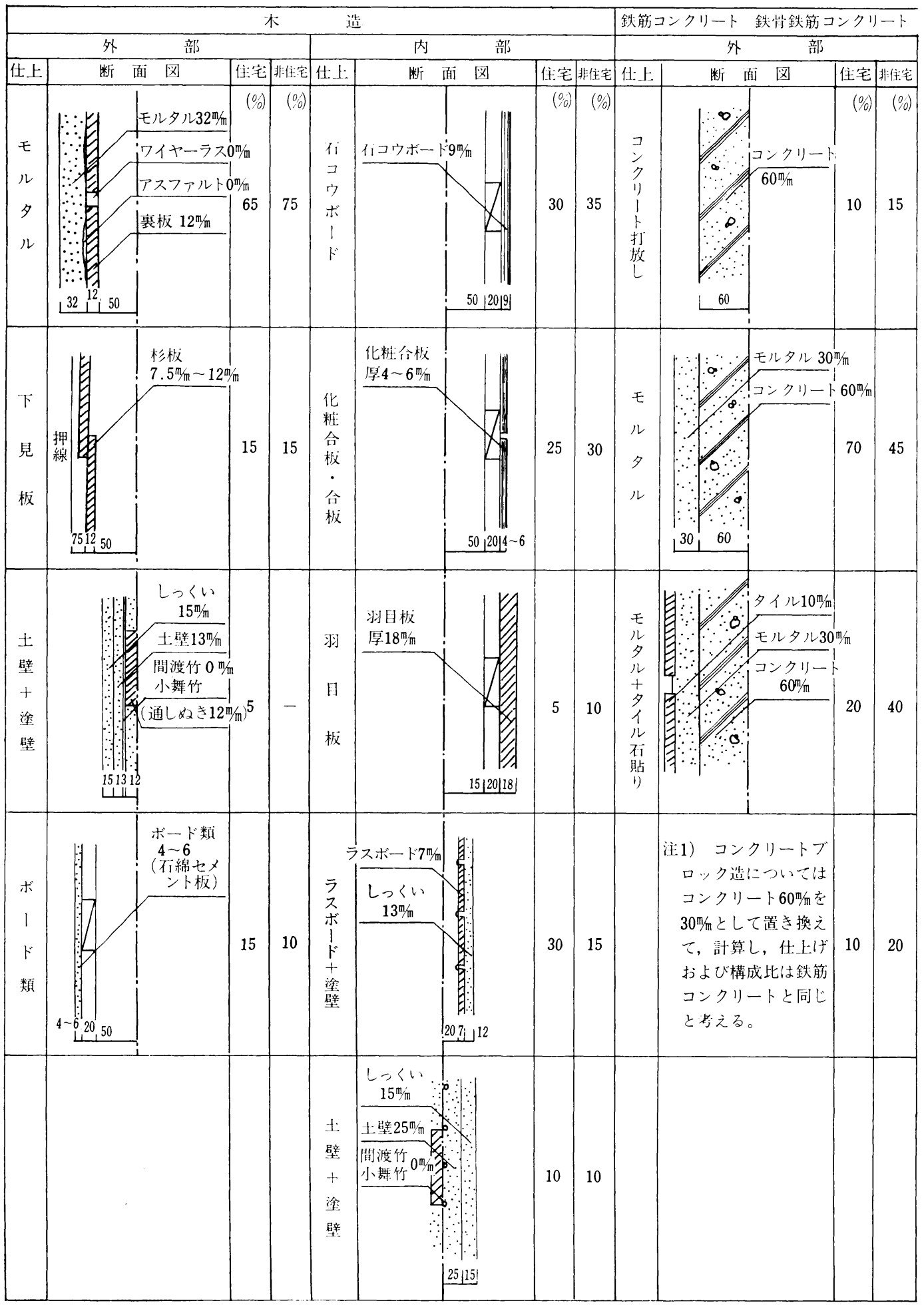

第 3 図建物構造別壁エレメント構成表 


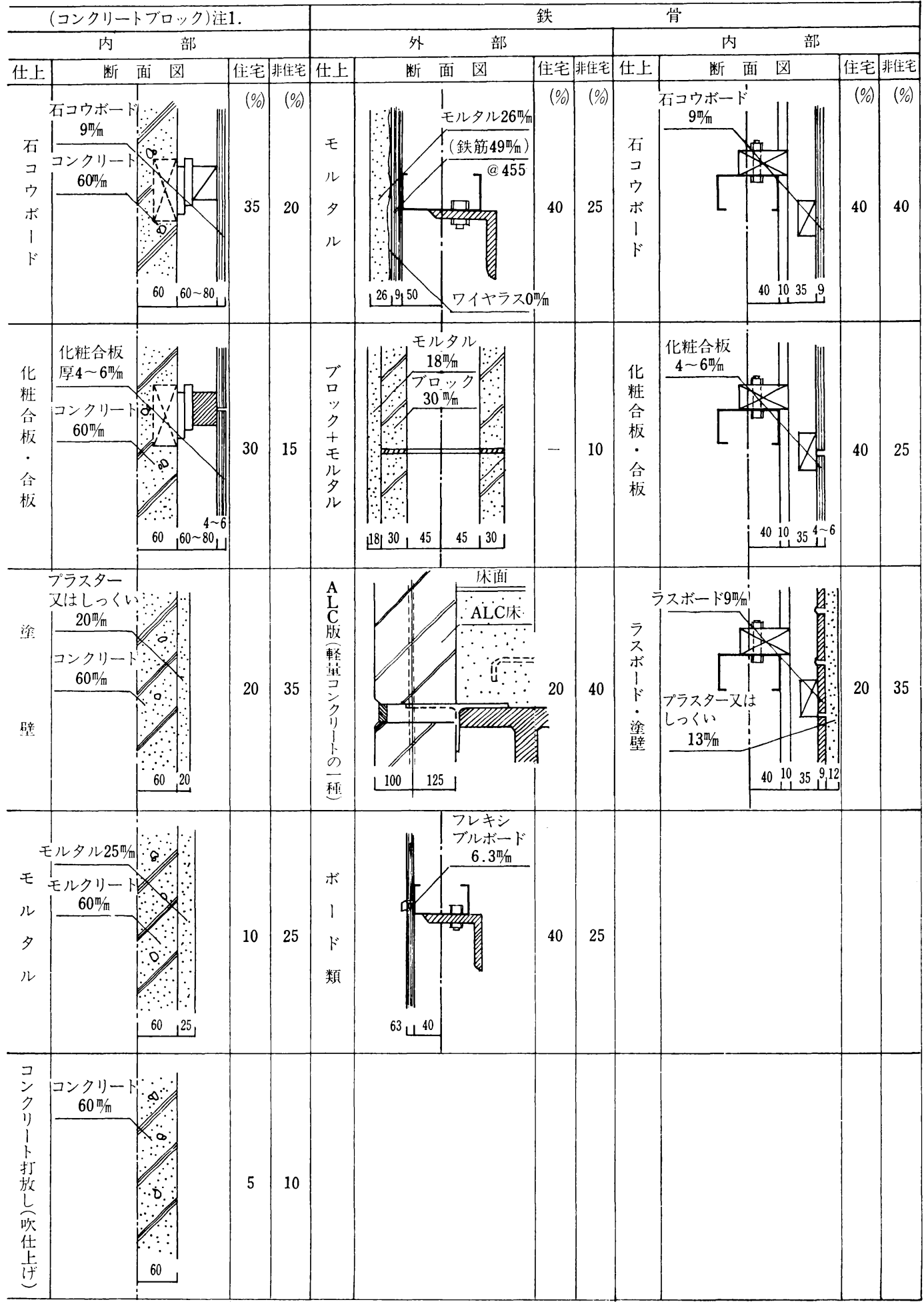

文献 1）から引用した. 
第 2 表 用途別開口率, 壁非開口率, 屋根・床・壁面積比*

\begin{tabular}{|c|c|c|c|c|c|c|}
\hline & & 居 & 住 $\left(\mathrm{m}^{2} / \mathrm{m}^{2}\right)$ & 公 共 $\left(\mathrm{m}^{2} / \mathrm{m}^{2}\right)$ & 商 & 工 $\left(\mathrm{m}^{2} / \mathrm{m}^{2}\right)$ \\
\hline 壁面積率 & $(\alpha)^{* *}$ & & $1.4 \sim 2.5$ & $0.8 \sim 2.0$ & & $0.2 \sim 1.0$ \\
\hline 開口率 & $(\beta)$ & & $0.3 \sim 0.5$ & $0.2 \sim 0.4$ & & $0.1 \sim 0.3$ \\
\hline 非開口率 & $(\gamma)$ & & $1.1 \sim 2.0$ & $0.6 \sim 1.6$ & & $0.1 \sim 0.7$ \\
\hline 屋根面積率 & $(\delta)$ & & 1 & 1 & & 1 \\
\hline 床面積率 & $(\delta)$ & & 1 & 1 & & 1 \\
\hline
\end{tabular}

* 文献 1）から引用した。

** $\alpha-\beta=\gamma$. これらの値は延床面積 $\left(\mathrm{m}^{2}\right)$ に対する面積 $\left(\mathrm{m}^{2}\right)$ の比である。

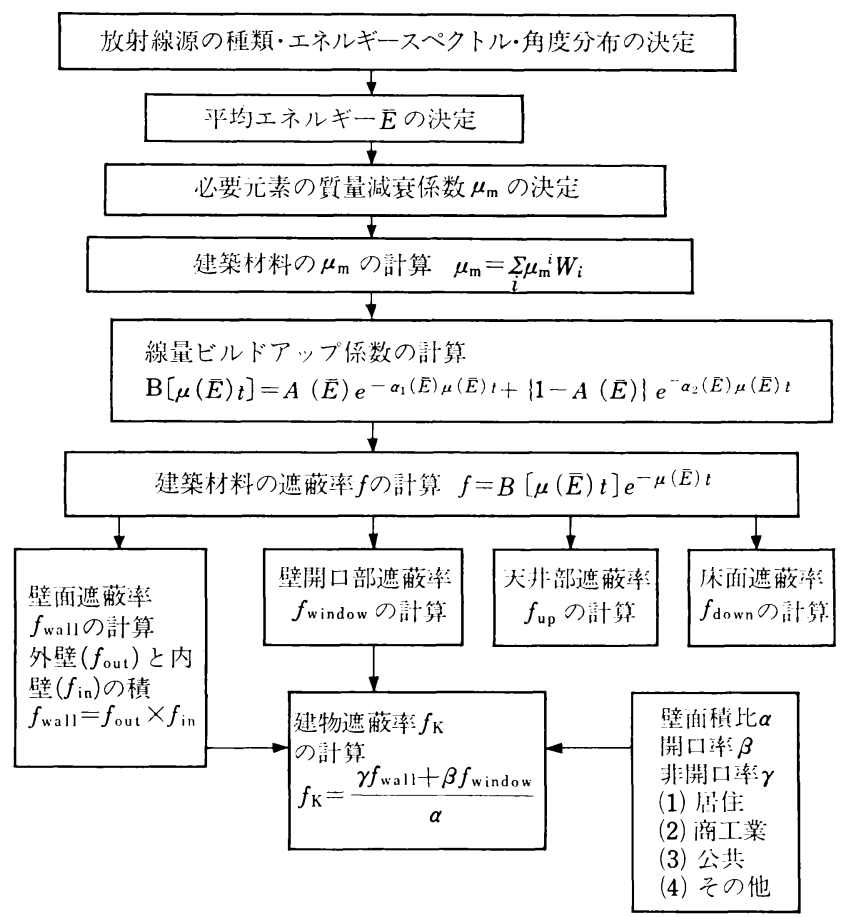

第 4 図建物遮蔽率計算のためのフローチャート

吸収係数 $\mu_{\mathrm{m}}\left(\mathrm{cm}^{2} / \mathrm{g}\right)$ は, 文献 9), 10) 飞与えられて いる元素 $(\mathrm{Ca}, \mathrm{Fe}, \mathrm{O}, \mathrm{C}, \mathrm{Mg}, \mathrm{S})^{9)}$, 化合物 $\left(\mathrm{SiO}_{2}\right.$, $\left.\mathrm{H}_{2} \mathrm{O}\right)^{9)}$ ，混合物（普通コンクリート ${ }^{9}$ ， ガラス ${ }^{10)}$ ， レン $\left.カ^{100}\right)$ の $\mu_{\mathrm{m}}$ のデータから, 各素材構成成分の重量比 $W(\%)$ を用いて

$$
\mu_{\mathrm{m}}=\sum_{i} \mu_{\mathrm{m} i} W_{i}
$$

より計算した。計算で求めた化合物は生石灰 $(\mathrm{CaO})$, 石 灰 $\left(\mathrm{CaCO}_{3}\right)$, 石綿 $\left(3 \mathrm{MgSiO}_{3} \cdot \mathrm{CaSiO}_{3}\right)$, 石こう $\left(\mathrm{CaSO}_{4}\right.$. $\left.2 \mathrm{H}_{2} \mathrm{O}\right)$ であり, 混合物は次のようにとり扱った。 i）セメントー $\mathrm{CaO} 30 \mathrm{wt} \%, \mathrm{SiO}_{2} 70 \mathrm{wt} \%$

ii ）モルタル一水 $10 \mathrm{wt} \%$, 砂 $\left(\mathrm{SiO}_{2}\right) 20 \mathrm{wt} \%$, セ丈 ント $70 \mathrm{wt} \%$

iii）コンクリート一文献 9）に用いられた組成は $\mathrm{H}$ $0.56 \mathrm{wt} \%, \mathrm{O} 49.83 \mathrm{wt} \%$, Na $1.71 \mathrm{wt} \%, \mathrm{Mg} 0.24$ wt $\%$, Al 4.56 wt $\%$, Si 31.58 wt $\%$, S 0.12 wt $\%$, K $1.92 \mathrm{wt} \%$, Ca $8.26 \mathrm{wt} \%, \mathrm{Fe} 1.22 \mathrm{wt} \%$ であ る。

iv）鉄筋コンクリートーュンクリート $96 \mathrm{wt} \%$ ，鉄 4 $\mathrm{wt} \%$ (この重量比率は用途別構造別建築材料使用量 
表1゙より推定した)

v) 鉄筋モルタルーモルタル $96 \mathrm{wt} \%$, 鉄 $4 \mathrm{wt} \%$ (こ の重量比率は鉄筋コンクリートに等しいと仮定し た)

vi）レンガ一文献 10）に用いられた組成は O $47.8 \mathrm{wt}$ $\%$, Si 28.0 wt $\%$, Al 10.9 wt \%, Ti 0.6 wt $\%, \mathrm{Fe}$ $4.2 \mathrm{wt} \%, \mathrm{Ca} 3.6 \mathrm{wt} \%, \mathrm{Mg} 2.6 \mathrm{wt} \%, \mathrm{~K} 1.8 \mathrm{wt}$ $\%, \mathrm{Na} 0.5 \mathrm{wt} \%$ である。

vii）プラスター拉よびしっくい一石灰 $90 \mathrm{wt} \%$, 水 10 $\mathrm{wt} \%$

viii）セメントボードーセメント 85 wt \% , 石綿 15 wt \%

ix) タイル一同じ成分を持ち密度だけが異なるレンガ の $\mu$ の值 ${ }^{10)}$ から求めた。

x）木材一第 1 表に示したよらに，普通合板に対する 1. $25 \mathrm{MeV}$ ガンマ線の実測值 $\mu_{\mathrm{m}}=0.0667 \mathrm{~cm}^{2} / \mathrm{g}$ が 水の值 ${ }^{9)} \mu_{\mathrm{m}}=0.0641 \mathrm{~cm}^{2} / \mathrm{g}$ にほぼ等しいこと,さ らに文献 11）にある木（Ash）の $\mu_{\mathrm{m}}$ 值が同様に 水の值に近いことから水で执きか光, 密度 $\rho$ のみを かえて $\mu$ を求めた。

xi）土一文献 10）に与只られているが，実際上この $\mu_{\mathrm{m}}$ 值は $\mathrm{SiO}_{2}$ のそれとほとんど等しいので，デー タの足りない所は $\mathrm{SiO}_{2}$ でおきかえた。

xii) 軽量コンクリートー $\mu$ (軽量コンクリート) $=\mu_{\mathrm{m}}$ （普通コンクリート） $\times \rho$ (軽量コンクリート密度) と して求めた。

xiii）コンクリートブロックーブロック空洞部を体 積 比で全体の $1 / 2$ と考え，壁厚 $t$ を実際の厚さの $1 / 2$ ととることにして， $\mu_{\mathrm{m}}$ や $\mu$ は普通コンクリートの 値を用いた。

xiv) 石綿セメント板・フレキシブルボードーセメン トボートと同じと考えた。

xv）石コウボードー石コウと同じと考えた。

xvi）ラスボードー石コウとみなすが，石コウボード

に穴があいている $(22 \mathrm{~cm} \times 22 \mathrm{~cm} \times 0.9 \mathrm{~cm}$ の板に $0.55 \mathrm{~cm} \phi$ の貫通孔 100 個を持つ）ので，それによ る密度の減少を考慮して $\mu$ を求めた。

xvii）屋根がわら一土と同じと考えた。

xviii）金属板屋根一鉄と同じと考えた。

xix) たたみ一木材と同じと考えた。

xx）ガラス一文献 10）の RS 253 クラウンガラスの $\mu$ 值を用いた。

以上の考えに基づいて建築材料に対して求められた質 量吸収係数が密度とともに第 3 表に示されている。なお これらの wt\% や密度は文献 12)，13）から推定した。
また厚さは第 3 図の壁エレメント構成表から求めた。こ の表から水，タイルを除くと汪とんど $\mu_{\mathrm{m}}$ の值は等しい ことが分るが，これはコンプトン散乱が主反応である 1 $\mathrm{MeV}$ 近辺のエネルギーでは質量吸収係数 $\mu_{\mathrm{m}}$ が物質に よらずほぼ一定であるという事実を反映している。

\section{4. 線量ビルドアップ係数の計算}

水，鉄，ガラスの 3 物質に対する線量ビルドアップ係 数Bは文献 10），14）にそのものが与えられており，普 通コンクリートに対しては, 文献 10）に線量ビルドア ップ係数に関する Taylor の式

$$
B(\mu t)=A e^{-\alpha_{1} \mu t}+(1-A) e^{-\alpha_{2} \mu t}
$$

のパラメータ $A, \alpha_{1}, \alpha_{2}$ が与兄られてい。この 4 つ の物質に対する $B$ ですべての建築材料に対する $B$ を第 3 表に示すように打きかえた。また，水，鉄に対しては， 点等方線源と平面一方向線源の両方に対する線量ビルド アップ係数が文献 14) に与えられており，大地放射線 に対しては後者の方がより適切なので後者の $B$ 值を採用 した。コンクリート，ガラスについては点等方線源に対 する $B$ 值しか文献 10）に与えられていないのでそれを 用いた。コンクリートの場合はパラメータ $A, \alpha_{1}, \alpha_{2}$ を，水，鉄，ガラスの場合は $B$ そのものを，平均エネル ギー $E$ に対して直線内捜により求めた。

\section{5. 建築材料別遮蔽率の計算}

第 3 図の壁エンメント構成表および文献 2 ）に与えら れている屋根, 床エレメント構成に従って, 建築材料別 エレメント構成別 (suffix; $n$ ) の遮蔽率 $f_{\mathrm{n}}$ は

$$
f_{\mathrm{n}}=B\left[\mu_{\mathrm{m}}(\bar{E}) \rho t\right] e^{-\mu_{\mathrm{m}}\left(\overline{E^{\prime}}\right), t}
$$

より求めた。この計算に必要な $\mu_{\mathrm{m}}, \rho, t, B$ の値は第 3 表に示した。

\section{6. 壁, 空, 屋根, 床遮蔽率の計算}

（1）壁遮蔽率 $f_{\text {wa11 }}$

これは外壁遮蔽率 $f_{\text {out }}$ と内壁遮蔽率 $f_{\text {in }}$ の積で与え られる。 $f_{\text {out }}$ と $f_{\text {in }}$ は建物構造別 (suffix； $m$ ) と仕上 げ材料別（suffix； $n$ ) に第 3 図扣よび第 3 表から計算し た。

(2) 空遮蔽率 $f_{\text {window }}$

これは材料がガラスのみであるから，空が閉っている 時はガラスの $f_{\mathrm{n}}$ の値に等しくなり，空が開いている時 は 1.0 となる。

（3） 屋根遮蔽率 $f_{\text {up }}$

木造の場合のみ仕上げ材料別に第 3 表から計算した。 非木造の場合は $f_{\text {up }}=f_{\text {wall }}$ と考えた。

(4) 床遮蔽率 $f_{\text {down }}$

木造の場合のみ仕上げ材料別に第 3 表から計算した。 非木造の場合は $f_{\text {down }}=f_{\text {wall }}$ と考光た。 
第 3 表 建築材料別遮蔽定数表

\begin{tabular}{|c|c|c|c|c|c|c|c|}
\hline \multirow{2}{*}{ 建築材料 } & \multicolumn{2}{|c|}{ 質量減衰係数 } & \multirow{2}{*}{$\begin{array}{c}\text { 密度 }{ }^{12,13)} \\
\rho\left(\mathrm{g} / \mathrm{cm}^{3}\right)\end{array}$} & \multirow{2}{*}{$\begin{array}{c}\text { 層の厚さ* } \\
t(\mathrm{~cm})\end{array}$} & \multicolumn{2}{|c|}{ 線量ビルドアップ率 } & \multirow{2}{*}{$\begin{array}{l}\text { 遮蔽率 } \\
(f)\end{array}$} \\
\hline & 相当物質 & $\left(\mathrm{cm}^{2} / \mathrm{g}\right)$ & & & 相当物質 & $(B)$ & \\
\hline \multirow[t]{3}{*}{ 木材（杉材） } & 水 & 0.0741 & 0.4 & 1.0 & 水 & 1.04 & 1.01 \\
\hline & & & & 1.2 & & 1.05 & 1.01 \\
\hline & & & & 1.8 & & 1.07 & 1.02 \\
\hline \multirow[t]{2}{*}{ 木材（床材） } & 水 & 0.0741 & 0.6 & 0.5 & 水 & 1.03 & 1.01 \\
\hline & & & & 2.0 & & 1.12 & 1.02 \\
\hline \multirow[t]{4}{*}{ モルタル } & モルタル** & 0.0675 & 2.0 & 1.8 & コンクリート & 1.28 & 1.01 \\
\hline & & & & 2.5 & & 1.40 & 0.996 \\
\hline & & & & 3.0 & & 1.48 & 0.985 \\
\hline & & & & 3.2 & & 1.51 & 0.980 \\
\hline 鉄筋モルタル & 鉄筋モルタル** & 0.0673 & 2.1 & 3.5 & コンクリート & 1.58 & 0.966 \\
\hline 土 & 水分 $10 \%$ の土 $\mathrm{SiO}$ & 20.0679 & 1.2 & 2.5 & コンクリート & 1.24 & 1.01 \\
\hline タイル & レンガ** & 0.0739 & 2.14 & 1.0 & コンクリート & 1.18 & 1.01 \\
\hline \multirow[t]{2}{*}{ ガラス } & ガラス** & 0.0667 & 2.5 & 0.3 & ガラス & 1.06 & 1.01 \\
\hline & & & & 0.5 & & 1.11 & 1.02 \\
\hline \multirow[t]{3}{*}{ コンクリート } & コンクリート** & 0.0668 & 2.35 & 3.0 & コンクリート & 1.56 & 0.971 \\
\hline & & & & 6.0 & & 2.13 & 0.830 \\
\hline & & & & 12.0 & & 3.33 & 0.506 \\
\hline \multirow[t]{2}{*}{ 鉄筋コンクリート } & \multirow{2}{*}{\multicolumn{2}{|c|}{ 鉄筋コンクリート**0.0668 }} & 2.57 & 6.0 & コンクリート & 2.23 & 0.800 \\
\hline & & & & 12.0 & & 3.56 & 0.456 \\
\hline 軽量コンクリート & コンクリート & 0.0668 & 1.6 & 12.0 & コンクリート & 2.56 & 0.709 \\
\hline ALC 版 & コンクリート & 0.0668 & 0.6 & 12.0 & コンクリート & 1.57 & 0.969 \\
\hline \multirow{2}{*}{ プラスター } & プラスター** & 0.0675 & 1.6 & 1.3 & コンクリート & 1.16 & 1.01 \\
\hline & & & & 2.0 & & 1.25 & 1.01 \\
\hline \multirow[t]{3}{*}{ Lnくw } & プラスター & 0.0675 & 1.1 & 1.3 & コンクリート & 1.11 & 1.01 \\
\hline & & & & 1.5 & & 1.13 & 1.01 \\
\hline & & & & 2.0 & & 1.17 & 1.01 \\
\hline 石綿セメント板 & セメントボード** & 0.0667 & 1.6 & 0.5 & コンクリート & 1.06 & 1.01 \\
\hline フレキシブルボード & セメントボード & 0.0667 & 1.75 & 0.63 & コンクリート & 1.09 & 1.01 \\
\hline 石コウボード & 石コウ** & 0.0683 & 1.1 & 0.9 & コンクリート & 1.08 & 1.01 \\
\hline \multirow[t]{2}{*}{ ラスボード } & 石コウ & 0.0683 & 1.0 & 0.7 & コンクリート & 1.06 & 1.01 \\
\hline & & & & 0.9 & & 1.07 & 1.01 \\
\hline かわら & 水分 $10 \%$ の土 & 0.0673 & 2.0 & 1.5 & コンクリート & 1.24 & 1.01 \\
\hline 石綿スレート板 & セメントボード & 0.0667 & 1.5 & 0.63 & コンクリート & 1.07 & 1.01 \\
\hline モルタルスレート板 & モルタル & 0.0675 & 2.0 & 1.5 & コンクリート & 1.24 & 1.01 \\
\hline 金属板 & 鉄 & 0.0626 & 7.86 & 0.5 & 鉄 & 1.23 & 0.964 \\
\hline たたみ & 水 & 0.0741 & 0.23 & 6.0 & コンクリート & 1.14 & 1.03 \\
\hline
\end{tabular}

* 文献 1）から引用した第 3 図の值を使用した.

** 組成については本文参照のこと. 


\section{7. 建物遮蔽率の計算}

実際の建物を考えた場合は，建物全体は壁，空，屋根 床の 4 部分から成立っているから，上記 4 種の遮蔽率を 組合わせて建物遮蔽率 $f_{\mathrm{K}}$ を求めねばならない。これら 4 部分が延床面積に対し, 各々どれ位の割合を占めてい るのかを示す, 単位延床面積当りの壁面 積 比 $\alpha\left(\mathrm{m}^{2} /\right.$ $\left.\mathrm{m}^{2}\right)$, 開口率 $\beta\left(\mathrm{m}^{2} / \mathrm{m}^{2}\right)$, 非開口率 $\gamma\left(\mathrm{m}^{2} / \mathrm{m}^{2}\right)$, 屋 根・床面積比 $\delta\left(\mathrm{m}^{2} / \mathrm{m}^{2}\right)$ が必要であるが，これらは前 述のように第 2 表に用途別（suffix； $i$ ) に示されている。 この值を用いることにより，Aを延床面積とすると建物 遮蔽率 $f_{\mathrm{K}}$ は次式のよらに表わされる。

$$
f_{\mathrm{K}}(m, n, i)=\frac{\gamma_{i} f_{\mathrm{wa} 11}+\beta_{i} f_{\text {window }}+\delta_{i}\left\{f_{\mathrm{up}}+f_{\mathrm{down}}\right\}}{\alpha_{i}+2 \delta_{i}}
$$

もし屋根および床の遮蔽効果を考えないことにすると，

$$
f_{\mathrm{K}}(m, n, i)=\frac{\gamma_{i} f_{\text {wall }}(m, n)+\beta_{i} f_{\text {window }}(m, n)}{\alpha_{i}}
$$

となる。

\section{V 計算結果と検討}

以上述べてきた計算方法によって求めた，平均エネル
ギー $\bar{E}=0.914 \mathrm{MeV}$ のガンマ線に対する建築材料の遮 蔽率 $f_{\mathrm{n}}$ を第 3 表に示す。表より， $f_{\mathrm{n}}$ の值はコンクリ 一トを除いてはほとんぞ 1.0 に近く, 遮蔽効果が注とん どないことがわかった。また，第 3 表から空（ガラス）, 木造建物の屋根（かわら，石綿スレート板，モルタルス レート板，金属板），木造建物の床（たたみ，フローリン グ材）の遮蔽率 $f_{\text {window }}, f_{\text {up }}, f_{\text {down }}$ はいずれも 1.0 と考えてよいことがわかった。

以上の結果と, 前にのべたように大地放射線が主とし て横方向つまり壁面から入射することとを考兄合わせ て, 今回の集団線量推定に際しては, すべての建物構造 に対して屋根扣よび床の遮蔽効果は無視することとし て，(7）式を用いて建物遮蔽率 $f_{\mathrm{K}}$ を求めた。この $f_{\mathrm{K}}$ の計算は建物構造別に居住用, 公共用, 商工業用の 3 つ の用途汶対して，各々第 2 表の $\alpha, \beta, \gamma$ の最大值と最 小值の 2 つの值について，仕上げ材別に行なった。この 計算結果から，木造建物に対しては，仕上げ材および用 途に無関係に $f_{\mathrm{K}}$ の值はすべて 1.0 に等しいとみなす ことができ，鉄筋コンクリートの場合はコンクリート 壁（打放し, モルタル張り, モルタル・石張り）と補強 コンクリートブロック壁の 2 つに $f_{\mathrm{K}}$ の值が大別でき, また鉄骨の場合はモルタル扣よび ALC 版壁, ボード類

第 4 表 集団線量推定に用いた遮蔽率

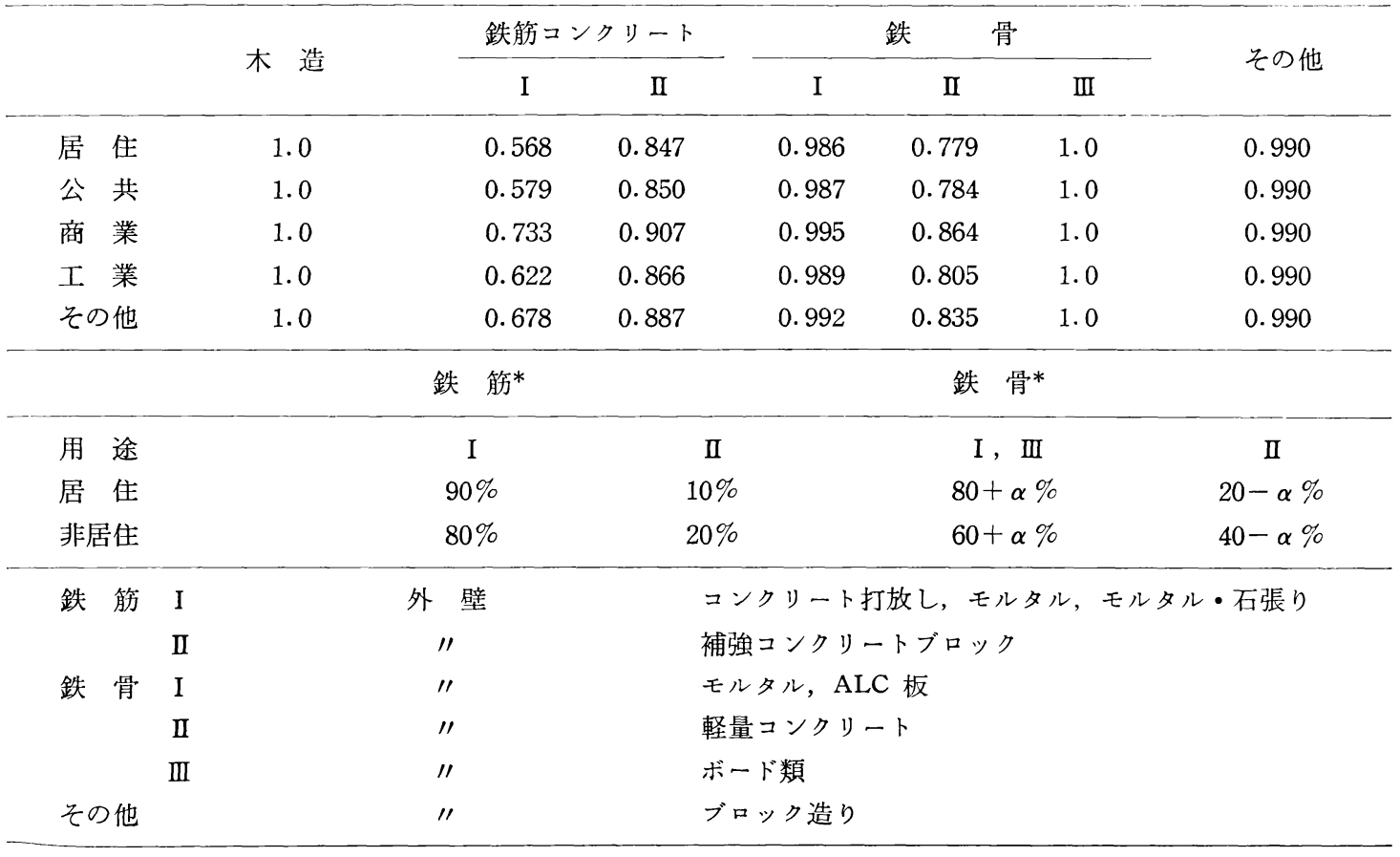

* 文献 1）から引用した第 3 図の値に基いて算出した。 
第 $\mathbf{5}$ 表 平均個人線量とそれに及ぼす宇宙線执よび大地放射線の寄与率

\begin{tabular}{|c|c|c|c|c|c|c|c|c|c|c|}
\hline \multirow[b]{2}{*}{ 対象地域 } & \multirow[b]{2}{*}{$\begin{array}{c}\text { 宇宙線 } \\
\left.\text { 線量15) }{ }^{2} \text { ( } \mu \text { rem } / \mathrm{hr}\right)\end{array}$} & \multirow[b]{2}{*}{$\begin{array}{c}\text { 大地放射 } \\
\text { 線線量 }{ }^{16)} \\
(\mu \mathrm{rem} / \mathrm{hr})\end{array}$} & \multirow[b]{2}{*}{$\begin{array}{l}\text { 平均個人 } \\
\text { 線量 } \\
\text { (mrem/y) }\end{array}$} & \multirow[b]{2}{*}{$\begin{array}{c}\text { 宇宙線 } \\
\text { の寄与 } \\
\text { (mrem/y) }\end{array}$} & \multicolumn{6}{|c|}{ 大地放射線の寄与 (mrem/y) } \\
\hline & & & & & 合 計 & $\begin{array}{l}\text { 自宅 } \\
\text { 内存 } \\
\text { 在時 }\end{array}$ & $\begin{array}{l}\text { 職場 } \\
\text { 学校 } \\
\text { 存在 } \\
\text { 時 }\end{array}$ & $\begin{array}{l}\text { その } \\
\text { 他施 } \\
\text { 設存 } \\
\text { 在時 }\end{array}$ & $\begin{array}{l}\text { 車中 } \\
\text { 存在 } \\
\text { 時 }\end{array}$ & $\begin{array}{l}\text { 屋外 } \\
\text { 存在 } \\
\text { 時 }\end{array}$ \\
\hline 東京都 & 3.0 & 2.96 & & & & & & & & \\
\hline 最小値 & & & 49.8 & 26.3 & 23.5 & 16.8 & 2.4 & 1.8 & 0.4 & 2.1 \\
\hline 最大値 & & & 51.5 & 26.3 & 25.2 & 17.9 & 2.8 & 2.1 & 0.4 & 2.1 \\
\hline 最確値 & & & 50.2 & 26.3 & 23.9 & 17.0 & 2.6 & 1.9 & 0.4 & 2.1 \\
\hline \multirow[t]{2}{*}{ 寄与率(\%) } & & & 100 & 52.4 & 47.6 & & & & & \\
\hline & & & & & その内訳 $(\%)$ & 71.1 & 10.8 & 7.7 & 1.6 & 8.7 \\
\hline 大阪府 & 3.0 & 4.96 & & & & & & & & \\
\hline 最小值 & & & 65.8 & 26.3 & 39.5 & 28.8 & 3.8 & 3.0 & 0.6 & 3.5 \\
\hline 最大值 & & & 68.5 & 26.3 & 42.2 & 30.5 & 4.4 & 3.4 & 0.6 & 3.5 \\
\hline 最確値 & & & 66.6 & 26.3 & 40.3 & 29.1 & 4.1 & 3.1 & 0.6 & 3.5 \\
\hline \multirow[t]{2}{*}{ 寄与率(\%) } & & & 100 & 39.5 & 60.5 & & & & & \\
\hline & & & & & その内訳 (\%) & 72.2 & 10.0 & 7.6 & 1.4 & 8.6 \\
\hline 茨城県 & 3.0 & 4.24 & & & & & & & & \\
\hline 最小値 & & & 61.6 & 26.3 & 35.3 & 25.8 & 2.7 & 2.5 & 0.4 & 3.9 \\
\hline 最大值 & & & 62.9 & 26.3 & 36.6 & 26.3 & 3.1 & 2.8 & 0.4 & 3.9 \\
\hline 最確值 & & & 62.0 & 26.3 & 35.7 & 25.9 & 2.9 & 2.6 & 0.4 & 3.9 \\
\hline \multirow[t]{2}{*}{ 寄与率(\%) } & & & 100 & 42.4 & 57.6 & & & & & \\
\hline & & & & & その内訳 $(\%)$ & 72.5 & 8.2 & 7.2 & 1.2 & 10.8 \\
\hline 長野県 & $3.8^{*}$ & 4.24 & & & & & & & & \\
\hline 最小値 & & & 69.0 & 33.5 & 35.5 & 25.6 & 3.0 & 2.5 & 0.5 & 3.9 \\
\hline 最大值 & & & 70.1 & 33.5 & 36.6 & 26.0 & 3.5 & 2.8 & 0.5 & 3.9 \\
\hline 最確値 & & & 69.3 & 33.5 & 35.8 & 25.7 & 3.3 & 2.6 & 0.5 & 3.9 \\
\hline \multirow[t]{2}{*}{ 寄与率(\%) } & & & 100 & 48.3 & 51.7 & & & & & \\
\hline & & & & & その内訳 (\%) & 71.8 & 9.1 & 7.2 & 1.3 & 10.8 \\
\hline
\end{tabular}

* 長野県の宇宙線線量は平均高度 $(500 \mathrm{~m})$ 飞対する実効値。

壁，軽量コンクリート壁の 3 つに分けることができた。 鉄骨のボード類壁およびその他の構造（ブロック造り） に対する $f_{\mathrm{K}}$ は用途によりほとんど変化しないので，用 途に無関係に平均值を求めた。な扣計算結果が 1.0 をほ んの少し越えた（1.01〜1.04）木造および鉄骨ボード類 壁の $f_{\mathrm{K}}$ の值は計算上の誤差とみなしてすべて 1.0 と した。鉄筋コンクリートおよび鉄骨（ボード類壁を除く） については, 居住用, 公共用建物の場合は $\alpha, \beta$ の最大 值と最小值に対し $f_{\mathrm{K}}$ の值がたがいによく似ているので その平均値を $f_{\mathrm{K}}$ とし, 商工業用建物の場合はかなり違 っているため，商業用建物は一般に工業用建物より開口
部が大きいことから $\alpha, \beta$ の最大值 $(\beta / \alpha=0.3 / 1.0=$ $0.3)$ を工業用， $\alpha, \beta$ の最小値 $(\beta / \alpha=0.1 / 0.2=0.5)$ を商業用としてふり分け, さらに両者の平均值をその他 の用途の建物とした。

以上の仮定に基いて，最終的に集団線量の推定に用い た建物遮蔽率 $f_{\mathrm{K}}$ の一覧表を第 4 表に示す。ただし鉄骨 の I (モルタル・ALC 版) とIII（ボード類）は $f_{\mathrm{K}}$ の值 がほとんど等しいので実際上一つにまとめても十分であ る。第 4 表には，第 3 図の用途別仕上げ材別の存在割 合1) から得られる鉄筋 I (ニンクリート打放し，モルタ ル張り, モルタル・石張り）とII（補強コンクリートブ 
第 6 表 対象地域別 Occupancy Factor

\begin{tabular}{lcccccccc}
\hline & \multicolumn{2}{c}{ 東京都 $(\%)$} & \multicolumn{2}{c}{ 大阪府 $(\%)$} & \multicolumn{2}{c}{ 茨城県 $(\%)$} & \multicolumn{2}{c}{ 長野県 $(\%)$} \\
& OF-1* & OF-2* & OF-1 & OF-2 & OF-1 & OF-2 & OF-1 & OF-2 \\
\hline 最小值 & 95.4 & 90.5 & 94.5 & 91.0 & 97.0 & 95.1 & 97.9 & 95.4 \\
最大值 & 98.5 & 97.1 & 98.3 & 97.3 & 99.0 & 98.5 & 99.3 & 98.5 \\
最確值 & 96.2 & 92.3 & 95.5 & 92.8 & 97.8 & 96.1 & 98.2 & 96.5 \\
\hline
\end{tabular}

* OF-1, OF-2 についての定義は本文参照のこと。

ロック）および鉄骨 I， III III（軽量コンクリート）の 存在割合を与えた。この数值からみて, 大部分の鉄筋, 鉄骨建造物は鉄筋 I および鉄骨 I， IIIであるといえよう。 したがって遮蔽率の最小值として鉄筋 I , 鉄骨 II の組合 せ，最大値として鉄筋 II，鉄骨 IIIの組合せ，代表値（最 確值) として鉄筋 I，鉄骨 I の組合せを選べばよいこと が結論づけられた。

\section{VI 集団線量への建築物遮蔽効果の影響}

第 4 表に示した鉄筋コンクリート I，II打よび鉄骨 I， II, III 計 6 と抢りの遮蔽率の組合せに対し, 東京都, 大阪府, 茨城県, 長野県の 4 地域に淤ける集団線量が推 定された。このうち最小值（鉄筋 I, 鉄骨 II), 最大值 (鉄筋 II , 鉄骨 III), 最確值（鉄筋 I , 鉄骨 I ）の 3 つの 場合について平均個人線量をまとめると第 5 表のように なった。な扢この計算に使用した宇宙線線量，大地放射 線線量, 人口分布・生活時間等は, 各々文献 15), 16),

（2）の值を引用している。

表からわかるように, 建物の遮蔽効果の差異による平 均個人線量の偏差 (したがって集団線量の偏差)は東京都 大阪府で約 $4 \%$, 茨城県, 長野県で約 $2 \%$ である。集団 線量の偏差がこのように小さいのは, 遮蔽効果が大きく 異なる鉄筋，鉄骨建造物の利用度が小さいためである。 このことは, 大地放射線の線量への寄与のうち, 自宅内 存在時の寄与が表に示したように 4 都府県とも $70 \%$ 強 と大部分を占めており，かつ自宅の構造別存在率は，東 京・大阪で木造が $75 \%$ 強, 荻城・長野で $90 \%$ 強と大部

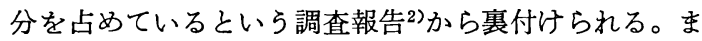
た，東京・大阪の偏差が茨城・長野の偏差よりやや大き いことも上記の木造建物存在率の差異に帰せられるであ ろう。

また，野外で 1 年間宇宙線や大地放射線を受けること を想定して算出される集団線量と, 本研究のように建筑 物の遮蔽効果, 生活時間等を考慮した実際の集団線量と の比を occupancy factor という。ここでは次の 2 つの occupancy factor を考えた。

[OF-1]

$$
=\frac{\text { 本研究による推定集団線量 }}{\text { 野外に敃ける宇宙線, 大地放射線起因集団線量 }}
$$

$[\mathrm{OF}-2]=\frac{\text { 本研究による大地放射線起因集団線量 }}{\text { 野外における大地放射線起因集団線量 }}$

本研究で推定した集団線量のらち, 遮蔽率の最大值, 最小值, 最確值に対する OF-1, OF-2 の値を第 6 表に 示した。 4 都府県とも, OF-1 は $95 \%$ を越えて打り, OF-2 は 90\% を越えていて, わが国の場合, 大都市地 域といえども遮敕効果の大きい鉄筋，鉄骨建築物に存在 している割合が小さく，建筑物遮蔽効果の影響が小さい (最大でも $10 \%$ 程度)ことがわかった。相対的にみると， 都市部の東京・大阪では OF-2 が 92 93\%, 茨城・長 野では 96 97\% となっていて, 建築物遮蔽効果の地域 差の影響が見られた。

本研究の遂行にあたり，この研究計画を立案され，そ の方向つけををれまた結果の検討をしていただいた放 射線影響協会の中に設けられた「国民線量推定のための 基礎調査委員会」の委員長，山県登氏（公衆衛生院放射 線衛生学部長) および委員諸氏市川龍資氏（放射線医学 総合研究所環境衛生部長), 吉沢晋氏 (公衆衛生院建築衛 生学部長), 飯島敏哲氏 (原子力研究所安全解析部環境調 查解析室長), 浜田達二氏 (理化学研究所主任研究員), 村山義彦氏（根本特殊化学株式会社副社長）, 阿部史朗 氏 (放射線医学総合研究所環境衛生部第一研究室長), 竹 下寿英氏（政策科学研究所主任研究員）に深く感謝致し ます。

\section{参考文 献}

1）財団法人放射線影響協会；国民線量推定のための 基礎調查（I ），(1978）.

2) 財団法人放射線影響協会; 国民線量推定のための 基礎調査（II）(1978). 
3) K.P. Beuermann; J. Geophys. Res., 76, 4291 (1971).

4) J.D. Thompson; J. Geophys. Res., 79, 1309 (1974).

5）湊 進; 環境放射線測定の現状之将来, 放射線医 学総合研究所環境セミナー報文集, p. 28 (1975).

6) H.L. BECK; The Natural Radiation Environment II, Proc. 2nd. Intern. Symp. on Natural Radiation Environment, p. 101 (1972).

7) 日本建築学会; 建築物荷重規準案, 同解説, 1975, 丸善, 東京.

8) 松下清夫; “各種建築構造図説”, (1972), 理工学 社, 東京.

9) J.H. Hubbell; Photon Cross Sections, Attenuation Coefficients and Energy Absorption Coefficients from $10 \mathrm{keV}$ to $100 \mathrm{GeV}$, NSRDSNBS-29 (1969).
10) R.G. JAEger et al. Ed. ; "Engineering Compendium on Radiation Shielding," Vol. II, Shielding Materials, 1975, Springer-Verlag, Berlin.

11) C.R. Tipton Jr. Ed.; "Reactor Handbook," Vol. I, Materials, p. 1096 (1960), Interscience Publ., New York.

12）藤井正一; “建材の実際知識”，1975，東洋経済新 報社, 東京.

13）日本建築学会; “建築設計資料集成”, p. 119(1978), 丸善, 東京.

14）兵藤知典; “放射線遮蔽入門”, p. 71 (1956), 産 業図書, 東京.

15）国連科学委員会報告 1977 年より阿倍史朗氏が内 挿して求めたもの.

16) 阿部史朗：私信. 